\title{
Community's Knowledge of COVID-19 and Its Associated Factors in Mizan-Aman Town, Southwest Ethiopia, 2020
}

This article was published in the following Dove Press journal: International Journal of General Medicine

\author{
Desalegn Feyissa Mechessa (D) \\ Fikadu Ejeta' \\ Lemi Abebe $\mathbb{I D}^{2}$ \\ Andualem Henok ${ }^{2}$ \\ Tadesse Nigussie $\mathbb{D}^{2}$ \\ Oliyad Kebede' \\ Yitagesu Mamo' \\ 'Department of Pharmacy, College of \\ Medicine and Health Science, Mizan-Tepi \\ University, Mizan-Aman, Ethiopia; \\ ${ }^{2}$ Department of Public Health, College of \\ Medicine and Health Science, Mizan-Tepi \\ University, Mizan-Aman, Ethiopia
}

Correspondence: Desalegn Feyissa Mechessa

Tel +25 I917/27556

Email sinaawayya@gmail.com
Background: Coronaviruses are a large group of viruses that are common throughout the community. They are associated with mortality, hospitalization, substantial extra costs and lower patient's quality of life. Thus, this study aimed to assess the community's knowledge of COVID-19 and associated factors in Mizan-Aman town, southwest Ethiopia.

Methods: Community-based cross-sectional study design was conducted among the community of Mizan-Aman from April 14 to May 14, 2020. A systematic sampling technique was used to collect data from selected households. Data were entered into Epi data version 4.0.2.101 and then exported to SPSS version 24.0 for analysis. To identify the predictors of knowledge of COVID-19, multiple backward logistic regression analysis was used. To show the accuracy of data analysis, 95\% CI was used, and statistical significance was considered at $\mathrm{p}<0.05$.

Results: From 423 sampled population, 393 (92.9\%) of them responded to the questionnaire. Of these, 233 (59.3\%) were male, 225 (57.3\%) were 18-34 years old, and $250(63.6 \%)$ were married. The overall correct rate of the knowledge questionnaire was $74.75 \%$. More than $85 \%$ of respondents were well aware of the main clinical symptoms of COVID-19, its transmission by close contact, its prevention by not going to crowded places and isolation of infected persons. Male gender $(\mathrm{AOR}=3.74, \mathrm{CI}: 1.87-7.49)$, age (35-54 years) $(\mathrm{AOR}=3.81$, CI: $1.35-10.70)$, age $\geq 55$ ( $\mathrm{AOR}=2.97$, $\mathrm{CI}: 1.16-7.62)$, lack of formal education $(\mathrm{AOR}=6.0$, CI: 1.54-23.40), farmer ( $\mathrm{AOR}=8.72$, CI: 2.08-35.53), daily laborer ( $\mathrm{AOR}=7.57, \mathrm{CI}: 2.28--$ 25.15), merchant $(\mathrm{AOR}=6.34, \mathrm{CI}: 2.06-19.43)$, house wife $(\mathrm{AOR}=11.59$, CI: 2.91-46.23) were significantly associated with poor knowledge, whereas single marital status was less likely associated with poor knowledge of COVID-19.

Conclusion: One-third of the study participants had poor knowledge regarding COVID-19. Male gender, age above thirty-five years, lack of formal education, being farmer, daily laborer, merchant and house wife were significantly associated with poor knowledge. Therefore, awareness creation should be given.

Keywords: community's, COVID-19, knowledge, Mizan-Aman, southwest Ethiopia

\section{Introduction}

Coronavirus $(\mathrm{CoV})$ infections are emerging respiratory viruses and are known to cause illnesses ranging from the common cold to severe acute respiratory syndrome (SARS). ${ }^{1}$ Its clinical presentations are characterized by acute respiratory distress syndrome, septic shock, metabolic acidosis, bleeding and coagulation dysfunction. ${ }^{2}$

The previous outbreaks of coronaviruses such as SARS-CoV and Middle East Respiratory Syndrome (MERS-CoV) in 2003 and 2015 showed similarities to the novel coronavirus, which was first reported by Chinese authorities in Wuhan city, 
the capital of Hubei province in China at the end of December 2019. It is currently the disease resulting in a worldwide outbreak. ${ }^{3,4}$

The virus is transmitted from humans to human via droplets coughed or exhaled by infected persons, and also by touching droplet-contaminated surfaces or objects and then touching the eyes, nose or mouth. ${ }^{5,6}$ The most commonly reported clinical symptom in laboratory-confirmed cases is fever, followed by dry cough, fatigue, sputum production, dyspnea, sore throat, headache with myalgia or arthralgia. ${ }^{7}$

Despite a global health crisis, there is currently no proven prophylaxis for those who have been exposed to COVID-19 and treatment for those who go on to develop COVID-19. However, many of the symptoms can be treated and getting early care from a healthcare provider can make the disease less dangerous. There are several clinical trials that are being conducted to evaluate potential therapeutics for COVID-19. ${ }^{8,9}$

The battle against COVID-19 is still continuing all over the world. ${ }^{10}$ The world Health Organization (WHO) set strategies to prevent and decline the transmission of COVID-19 such as frequent hand-washing with soap, avoiding close contact, staying home, covering mouth and nose with flexed elbow and maintaining social distancing. To guarantee the final success, people's adherence to these control measures is essential, which is largely affected by their knowledge of COVID-19. ${ }^{11,12}$

To facilitate outbreak management of COVID-19 in Ethiopia, there is an urgent need to assess the public's awareness of COVID-19 at this critical moment. Therefore, this study aimed to assess the knowledge of COVID-19 and its associated factors among the community of Mizan-Aman town, southwest Ethiopia. The findings of this study will help the responsible body organize the necessary interventional programs (education, demonstration) in order to provide up-to-date information to control COVID-19 disease.

\section{Methods}

\section{Study Area and Period}

This study was conducted in Mizan-Aman town, southwest Ethiopia, from April 14 to May 14, 2020. Mizan-Aman is a zonal town of the Benchi-Sheko Zone. It is one of the zones in Southern nation, nationalities, and people's region. It is 583 kilometers from Addis Ababa, the capital city of Ethiopia, to the southwest direction. Mizan-Tepi University, Mizan-Aman College of Health Science and Mizan-Aman
Town Health office disseminate health information to the residents face to face while Fana FM and Debub FM radios were delivering information using their stations.

\section{Study Design, Population and Sample}

A community-based cross-sectional study was conducted in Mizan-Aman town to assess the community's knowledge of COVID-19. All adults of Mizan-Aman town were the source population and all selected individuals who fulfilled the eligibility criteria were the study population.

\section{Inclusions and Exclusions Criteria}

Adults (age $\geq 18$ years) and who were permanent residents (greater than 6 months) of Mizan-Aman town were included in the study, whereas adults who were unwilling to respond and houses closed during data collection were excluded from the study.

\section{Sample Size Determination and Sampling Techniques}

The sample size was determined based on the single population proportion formula: $n=\left[\left(Z_{\alpha / 2}\right)^{2} p(1-p)\right] / d^{2}$ with the assumption of a $95 \%$ confidence interval $(\mathrm{Z \alpha} / 2=1.96)$, marginal error $(\mathrm{d})$ of $5 \%$ and $\mathrm{P}=50 \%$ with a $10 \%$ non-response rate, the required total sample size was 423 . Systematic random sampling was used to select sample households that represent the entire town. The interval, $\mathrm{K}$, was calculated by dividing total households by 423 . The sample household was selected systematically by jumping every 30 households. The first household was selected by the lottery method. From the selected household, the study participant was chosen by the lottery method if more than one eligible individual present.

\section{Study Variables}

In this study, the dependent variable was Knowledge, whereas independent variables included sex, age, marital status, ethnicity, religion, educational status, occupational status and presence of health professionals in the household.

\section{Data Collection Instrument and Procedure}

A structured questionnaire was adapted from similar literature, which contains 2 parts. Part I includes respondent's background data and Part II includes knowledgerelated questions. The questionnaire was translated into the local language (Amharic) by persons who were 
proficient in both languages. Then, the questionnaire was pre-tested on a $5 \%$ of the total sample size in a Kite Town, which is $8 \mathrm{Km}$ away from Mizan-Aman Town, and modified based on the pretest. Five experienced BSc public health and two supervisors were recruited and trained for data collection and supervision, respectively. The training was given for two days on how to ensure confidentiality, tool, how to protect themselves and community from infection and interview techniques. Additionally, the data collectors and supervisors adhered to the WHO and Ethiopian Ministry of Health guidelines on COVID-19 prevention. ${ }^{13,14}$ Accordingly, they maintained social distance, worn personal protective equipment and used an alcohol-based hand sanitizer during the data collection period. Data were collected through face-to-face interview method. The supervisors and principal investigators supervised the process of data collection on a daily basis.

\section{Outcome Measures}

A knowledge questionnaire was developed from different studies. ${ }^{15-17}$ The questionnaire had 12 questions with 3 regarding clinical presentations, 4 regarding transmission routes, and 5 regarding prevention and control of COVID19. These questions were answered on a true/false basis with an additional "I don't know" option. A correct answer was assigned 1 point and an incorrect/unknown answer was assigned 0 point. During the analysis, negatively worded items of knowledge (number 7 and 10) were reversely scored. The total knowledge score ranged from 0 to 12 , with a higher score denoting a better knowledge of COVID-19. The Cronbach's alpha coefficient of the knowledge questionnaire was calculated to the check internal consistency of the tool, which was 0.78 .

\section{Data Quality Assurance and Management}

Data quality was assured by careful selection and collection of complete and appropriate data. The clarity and completeness of data collection formats were checked before the actual data collection. Data were cleared before entered into Epi data manager version 4.0.2.101. The collected data were processed and retained cautiously in line with its objective. A 5\% sample pretest was performed on randomly selected residents before the beginning of the study.

\section{Data Processing and Analysis}

The data on questionnaire were entered into Epi data manager version 4.0.2.101 and double entry verification was made. The data were exported to SPSS version 24 statistical packages for analysis. The data were explored to check for outliers, missing data and assumptions. During analysis, frequencies and percentages were used to describe categorical variables, while means and standard deviations were used to describe continuous variables. Bivariate analysis was performed to select variables for multivariate analysis. Variables with a p-value $<0.25$ in the bivariate analysis were taken as candidates for multivariable analysis. Finally, a multivariable logistic model was created to predict the determinants of knowledge. P-value less than 0.05 was accepted as statistically significant variables.

\section{Operational Definition Knowledge}

Each correct answer in relation to the knowledge of COVID-19 was given one point. The total knowledge score varied between 0 (with no correct answer) and 12 (for all correct answers), and a cut off level of $<8$ was evaluated as poor knowledge, and $\geq 8$ indicated good knowledge. $^{15}$

\section{Ethical Clearance}

Ethical clearance was obtained from Mizan-Tepi University Ethics Review Board. The Mizan-Aman town administration office was informed about the purpose of the study to get permission. Both data collectors and supervisors adhered to the WHO and Ethiopian Ministry of Health COVID-19 prevention guidelines during data collection. Confidentiality of the respondents was secured by excluding respondent's identifiers like name and house number from the data collection format. Informed consent was obtained from the respondents before conducting the study.

\section{Results}

From a total of 423 sampled populations, 393 (92.9\%) of the study population responded to the questionnaire. The mean age of the study population was $33.85(\mathrm{SD} \pm 13.79)$ years. Two hundred thirty-three $(59.3 \%)$ were male, 250 (63.6\%) were married, $158(40.2 \%)$ were orthodox and $133(33.8 \%)$ were Bench in ethnicity. Eighteen percent of the participants had health care professionals in their homes (Table 1).

\section{Knowledge}

Mixed responses were obtained for 12 knowledge items. The mean COVID-19 knowledge score was 8.97 \pm 1.7 . More than $85 \%$ of respondents were well aware of the 
Table I Socio-Demographic Characteristics of Study Participants in Mizan-Aman Town, Southwest, Ethiopia, 2020

\begin{tabular}{|c|c|c|}
\hline Variables & Categories & $\begin{array}{l}\text { Frequency \% } \\
(n=393)\end{array}$ \\
\hline Sex & $\begin{array}{l}\text { Female } \\
\text { Male }\end{array}$ & $\begin{array}{l}160(40.7) \\
233(59.3)\end{array}$ \\
\hline Age & $\begin{array}{l}18-34 \\
35-54 \\
\geq 55 \\
\text { Mean +STD }\end{array}$ & $\begin{array}{l}225(57.3) \\
127(32.3) \\
41(10.4) \\
33.85+13.79\end{array}$ \\
\hline Religion & $\begin{array}{l}\text { Protestant } \\
\text { Orthodox } \\
\text { Muslim } \\
\text { Catholic } \\
\text { Jehovah's witness }\end{array}$ & $\begin{array}{l}108(27.5) \\
158(40.2) \\
114(29.0) \\
8(2.0) \\
5(1.3)\end{array}$ \\
\hline Ethnicity & $\begin{array}{l}\text { Bench } \\
\text { Amhara } \\
\text { Kafa } \\
\text { Oromo } \\
\text { Sheka } \\
\text { Other }^{\mathrm{a}}\end{array}$ & $\begin{array}{l}133(33.8) \\
\text { II } 8(30.0) \\
77(19.6) \\
30(7.6) \\
17(4.3) \\
18(4.6)\end{array}$ \\
\hline Marital status & $\begin{array}{l}\text { Married } \\
\text { Single } \\
\text { Widowed /Divorced }\end{array}$ & $\begin{array}{l}250(63.6) \\
122(31.0) \\
21(5.3)\end{array}$ \\
\hline Educational status & $\begin{array}{l}\text { No formal education } \\
\text { Primary education } \\
\text { Secondary school } \\
\text { University/ college }\end{array}$ & $\begin{array}{l}38(9.7) \\
159(40.5) \\
112(28.5) \\
84(21.4)\end{array}$ \\
\hline $\begin{array}{l}\text { Occupational } \\
\text { status }\end{array}$ & $\begin{array}{l}\text { Farmer } \\
\text { Employee } \\
\text { Daily labor } \\
\text { Merchant } \\
\text { Student } \\
\text { Unemployed/ } \\
\text { Housewife }\end{array}$ & $\begin{array}{l}31(7.9) \\
61(15.5) \\
60(15.3) \\
107(27.2) \\
99(25.2) \\
35(8.9)\end{array}$ \\
\hline
\end{tabular}

Note: Other ${ }^{\mathrm{a}}$ : Tigre, Gurage and Silte.

main clinical symptoms of COVID-19, its transmission by close contact, its prevention by not going to crowded places and isolation of infected persons. Additionally, $84.2 \%$ of the participants responded correctly for not all persons with COVID-19 will develop to severe cases, and (77.4\%) of them knew as COVID-19 virus spreads via respiratory droplets of infected individuals. Furthermore, two-thirds of participants knew that eating or contacting wild animals would result in infection and ordinary residents can wear general medical masks to prevent infection. However, when respondents asked questions related to transmission of COVID 19 in the absence of fever in infected persons, the importance of taking measures for infants and young children to prevent the infection and uncommon symptoms of COVID 19 compared to common cold, $66.4 \%, 54.7 \%$ and $49.1 \%$ of them were unable to identify correct answers, respectively. Generally, 35.4\% of the population had poor knowledge (Table 2). Differences in knowledge scores among different demographic characteristics were assessed using t-tests. The results show that knowledge scores were significantly different across age categories, educational status, presence of health professionals in households, occupation status and marital status (Table 3).

\section{Predictors of Knowledge}

Sex (male), age (35-54 and $>55$ years), marital status (single), educational status (no formal education), occupational status (farmer, student, unemployed/housewife) were significantly associated with poor knowledge of COVID-19 (Table 4).

\section{Discussion}

Currently, COVID-19 is a global discussion topic in the media and among the public. Until now, the outbreak is considered an emergency and the community has an increased risk of infection. However, up to our knowledge, there is no investigation of the community's knowledge of COVID-19 and its associated factors in this study area.

The findings in our study showed that the overall correct rate of the knowledge questionnaire was $74.75 \%$. This is lower than the study done in China where the overall correct rate of the knowledge questionnaire was $90 \% .{ }^{15}$ This discrepancy might be due to the difference in technology access and educational level between the study populations. In general, in our study, $35.4 \%$ of participants had poor knowledge about the disease, its mode of transmission, prevention and control.

In this study, $87.5 \%$ of the respondents knew that the main clinical symptoms of COVID-19 were fever, fatigue, dry cough, and myalgia and $73.8 \%$ of them knew as currently, there is no effective cure for COVID-2019, but early symptomatic and supportive treatment can help most patients recover from the infection. This is similar to the finding reported by Kebede et $\mathrm{al}^{18}$ where $83 \%$ of the respondents knew that the main clinical symptoms of COVID-19 are fever, fatigue, dry cough, and myalgia and $72.1 \%$ of respondents knew that currently, there is no effective cure for COVID-2019, but early symptomatic 
Table 2 Knowledge of Respondents Toward COVID-19 Among Residents of Mizan-Aman, Southwest Ethiopia, 2020

\begin{tabular}{|c|c|c|c|}
\hline \multirow[t]{2}{*}{ No. } & \multirow[t]{2}{*}{ Variables } & \multicolumn{2}{|l|}{ Response } \\
\hline & & Yes & No \\
\hline I & COVID-19 is transmitted by close contact with the infected person. & $352(89.6)$ & $4 I(10.4)$ \\
\hline 2 & The main clinical symptoms of COVID-19 are fever, fatigue, dry cough, and myalgia & $344(87.5)$ & $49(12.5)$ \\
\hline 3 & $\begin{array}{l}\text { Unlike the common cold, stuffy nose, runny nose, and sneezing are less common in persons } \\
\text { infected with the COVID-19 }\end{array}$ & $200(50.9)$ & $193(49.1)$ \\
\hline 4 & $\begin{array}{l}\text { Currently, there is no effective cure for COVID-2019, but early symptomatic and supportive } \\
\text { treatment can help most patients recover from the infection }\end{array}$ & $290(73.8)$ & $103(26.2)$ \\
\hline 5 & $\begin{array}{l}\text { Not all persons with COVID-2019 will develop to severe cases. Only those who are elderly, } \\
\text { have chronic illnesses (DM, HTN), and obese are more likely to be severe cases }\end{array}$ & $33 \mid(84.2)$ & $62(15.8)$ \\
\hline 6 & Eating or contacting wild animals would result in the infection by the COVID-19 virus. & $259(65.9)$ & $134(34.1)$ \\
\hline 7 & Persons with COVID-2019 cannot infect the virus to others when a fever is not present. & $132(33.6)$ & $261(66.4)$ \\
\hline 8 & The COVID-19 virus spreads via respiratory droplets of infected individuals. & $304(77.4)$ & $89(22.6)$ \\
\hline 9 & Ordinary residents can wear general medical masks to prevent the infection by the COVID-19 virus. & $245(62.3)$ & $148(37.7)$ \\
\hline 10 & $\begin{array}{l}\text { It is not necessary for children and young adults to take measures to prevent the infection by } \\
\text { the COVID-19 virus }\end{array}$ & $178(45.3)$ & $215(54.7)$ \\
\hline II & $\begin{array}{l}\text { To prevent the infection by COVID-19, individuals should avoid going to crowded places such as } \\
\text { train stations and avoid taking public transportations. }\end{array}$ & $352(89.6)$ & $41(10.4)$ \\
\hline 12 & $\begin{array}{l}\text { Isolation and treatment of people who are infected with the COVID-19 virus are effective ways } \\
\text { to reduce the spread of the virus. }\end{array}$ & $340(86.5)$ & $53(13.5)$ \\
\hline 13 & Overall knowledge & $\begin{array}{l}\text { Good knowledge } \\
=254(64.6)\end{array}$ & $\begin{array}{l}\text { Poor knowledge } \\
=139(35.4)\end{array}$ \\
\hline
\end{tabular}

Table 3 Socio-Demographic Characteristics of Participants and Knowledge Score Among Community of Mizan-Aman Town, Southwest Ethiopia, 2020

\begin{tabular}{|c|c|c|c|c|c|}
\hline \multirow[t]{2}{*}{ Variables } & \multirow[t]{2}{*}{ Categories } & \multirow[t]{2}{*}{ Frequency (\%), N=393 } & \multicolumn{3}{|c|}{ Knowledge Score } \\
\hline & & & Mean ( $\pm S D)$ & $\mathbf{t} / \mathbf{F}$ & p-value \\
\hline Sex & $\begin{array}{l}\text { Female } \\
\text { Male }\end{array}$ & $\begin{array}{l}160(40.70) \\
233(59.30)\end{array}$ & $\begin{array}{l}8.99(1.92) \\
8.95(1.59)\end{array}$ & 5.30 & 0.018 \\
\hline Age & $\begin{array}{l}18-34 \\
35-54 \\
\geq 55\end{array}$ & $\begin{array}{l}225(57.30) \\
127(32.30) \\
4 I(10.40)\end{array}$ & $\begin{array}{l}9.15(1.60) \\
8.56(1.98) \\
9.27(1.34)\end{array}$ & 5.50 & 0.004 \\
\hline Marital status & $\begin{array}{l}\text { Married } \\
\text { Single } \\
\text { Widowed /Divorced }\end{array}$ & $\begin{array}{l}250(63.60) \\
122(31.00) \\
21(5.30)\end{array}$ & $\begin{array}{l}8.97(1.72) \\
9.34(1.36) \\
6.86(1.97)\end{array}$ & 29.52 & 0.000 \\
\hline Educational status & $\begin{array}{l}\text { No formal education } \\
\text { Primary education } \\
\text { Secondary school } \\
\text { University/ college }\end{array}$ & $\begin{array}{l}38(9.70) \\
159(40.50) \\
112(28.50) \\
84(21.40)\end{array}$ & $\begin{array}{l}7.00(1.7) \\
8.29(1.34) \\
9.82(1.24) \\
10.00(1.20)\end{array}$ & 64.72 & 0.000 \\
\hline Occupational status & $\begin{array}{l}\text { Farmer } \\
\text { Employee } \\
\text { Daily labor } \\
\text { Merchant } \\
\text { Student } \\
\text { Unemployed/Housewife }\end{array}$ & $\begin{array}{l}31(7.90) \\
61(15.50) \\
60(15.30) \\
107(27.20) \\
99(25.20) \\
35(8.90)\end{array}$ & $\begin{array}{l}6.87(1.67) \\
9.93(1.14) \\
8.47(1.60) \\
9.26(1.44) \\
9.30(1.39) \\
8.17(1.75)\end{array}$ & 21.10 & 0.000 \\
\hline Presence of health care provider in household & $\begin{array}{l}\text { Yes } \\
\text { No }\end{array}$ & $\begin{array}{l}71(18.10) \\
322(81.90)\end{array}$ & $\begin{array}{l}9.94(1.39) \\
8.75(1.72)\end{array}$ & 29.52 & 0.000 \\
\hline
\end{tabular}


Table 4 Multivariable Logistic Regression of Community's Knowledge of COVID-19 and Its Association Factors in Mizan-Aman Town, Southwest, Ethiopia, 2020

\begin{tabular}{|c|c|c|c|c|c|c|}
\hline Variables & Categories & $\begin{array}{l}\text { Good } \\
\text { Knowledge }\end{array}$ & $\begin{array}{l}\text { Poor } \\
\text { Knowledge }\end{array}$ & COR & AOR & P-value \\
\hline \multirow[t]{2}{*}{ Sex } & Female & $113(70.6)$ & $47(29.4)$ & I & & \\
\hline & Male & |4| (55.5) & $92(39.5)$ & $\mathrm{I} .57(\mathrm{I} .02-2.4 \mathrm{I})$ & $3.74(1.87-7.49)$ & $0.000 *$ \\
\hline \multirow[t]{3}{*}{ Age } & $18-34$ & $154(68.4)$ & 71 (3I.6) & I & I & \\
\hline & $35-54$ & $72(56.7)$ & $55(43.3)$ & $0.99(0.48-2.03)$ & $3.81(1.35-10.70)$ & $0.011 *$ \\
\hline & $\geq 55$ & $28(68.3)$ & $13(3 \mid .7)$ & $\mathrm{I} .64(0.78-3.47)$ & $2.97(1.16-7.62)$ & $0.023 *$ \\
\hline \multirow[t]{3}{*}{ Marital status } & Married & I54 (6I.6) & $96(38.4)$ & I & & \\
\hline & Single & $94(77.0)$ & $28(23.0)$ & $0.48(0.29-0.78)$ & $0.452(0.22-0.91)$ & $0.026^{*}$ \\
\hline & Widowed/Divorced & $6(28.6)$ & I5 (7I.4) & $4.01(1.50-10.69)$ & $2.87(0.85-9.64)$ & 0.088 \\
\hline \multirow[t]{4}{*}{ Educational status } & No formal education & $7(18.4)$ & $31(8 I .6)$ & $24.18(8.80-66.48)$ & $6.0(1.54-23.40)$ & $0.010 *$ \\
\hline & Primary education & $79(49.7)$ & $80(50.3)$ & $5.53(2.83-10.78)$ & $2.43(0.98-5.90)$ & 0.059 \\
\hline & Secondary school & $97(86.6)$ & $15(13.4)$ & $0.84(0.38-1.88)$ & $0.442(0.17-1.13)$ & 0.089 \\
\hline & University/ college & 71 (84.5) & $13(15.5)$ & I & I & \\
\hline \multirow[t]{6}{*}{ Occupational status } & Employee & $55(90.2)$ & $6(9.8)$ & I & I & \\
\hline & Farmer & $6(19.4)$ & $25(80.6)$ & $38.19(11.2-130.2)$ & $8.72(2.08-35.53)$ & $0.003 *$ \\
\hline & Daily labor & $23(38.3)$ & $37(61.7)$ & I4.74 (5.47-39.70) & $7.57(2.28-25.15)$ & $0.00 I^{*}$ \\
\hline & Merchant & $78(78.8)$ & $21(2 \mid .2)$ & $3.09(1.19-7.99)$ & $6.34(2.06-19.43)$ & $0.001 *$ \\
\hline & Student & $80(74.8)$ & $27(25.2)$ & $2.46(0.93-6.5 \mathrm{I})$ & $2.32(0.74-7.3 \mathrm{I})$ & 0.150 \\
\hline & Unemployed/Housewife & $12(34.3)$ & $23(65.7)$ & $17.56(5.88-52.48)$ & II.59 (2.91-46.23) & $0.00 I^{*}$ \\
\hline Presence of health & Yes & $60(84.5)$ & II (I5.5) & I & I & \\
\hline professionals in Household & No & $194(60.2)$ & $128(39.8)$ & $3.56(1.82-7.10)$ & $2.26(0.93-5.5 I)$ & 0.073 \\
\hline
\end{tabular}

Note: *Statistically significant $(p<0.05)$.

and supportive treatment can help most patients recover from the infection.

Multiple logistic regression analysis of this finding showed that being male was significantly associated with poor knowledge of COVID-19 as compared to females. This is similar to a study done in China and Saudi Arabia, where male was significantly associated with low knowledge scores. ${ }^{15,19}$ In our finding age above 35 years was significantly associated with poor knowledge. This is in agreement with the study done in Egypt, where respondents' age older than 50 years were significantly associated with poor knowledge. ${ }^{16}$ However, this is in contrast to a study done in China where age above 30 years was associated with good knowledge. ${ }^{15}$

Lack of formal education was significantly associated with poor knowledge. This is similar to a previous study. ${ }^{15}$ The possible justification might be formal education providing basic infectious disease (such as the SARS-CoV) concept, mode of transmission and prevention. In this study, being unemployed was significantly associated with poor knowledge of COVID-19. This is in agreement with a previous report finding. ${ }^{15}$ In addition to this being farmer, daily laborer and merchants were significantly associated with poor knowledge of COVID-19.

However, being single in marital status was less likely associated with poor knowledge. Similarly, other previous study also demonstrated that being unmarried was associated with good knowledge. ${ }^{20}$ The possible reason might be that unmarried persons have less social and family responsibility, which reduces psychosocial burden, which in turn increases their knowledge.

\section{Conclusion}

One-third of the respondents had poor knowledge of the COVID-19 concept, transmission, prevention and control. Being male, age above 35 years, lack of formal education, being farmer, daily laborer, merchant and unemployed/ house wife were significantly associated with poor knowledge, whereas being single was less likely associated with poor knowledge of COVID-19.

\section{Abbreviations}

COVID-19, coronavirus disease 2019; KAP, knowledge attitude practice; MERS, Middle East respiratory 
syndrome; SARS, severe acute respiratory syndrome; WHO, World Health Organization.

\section{Data Sharing Statement}

All relevant data are within the paper.

\section{Acknowledgments}

We are also extended our gratitude to all individuals who were involved in data collection and also the participants who genuinely provided us with all necessary information.

\section{Author Contributions}

All authors made substantial contributions to the conception and design, acquisition of data, analysis and interpretation of data, took part in revising the article, gave final approval of the version to be published and agreed to be accountable for all parts of the work.

\section{Funding}

Not funded by any organization.

\section{Disclosure}

The authors declare that they have no competing interests.

\section{References}

1. Yin Y, Wunderink R. MERS, SARS and other coronaviruses as causes of pneumonia. Respirology. 2018;23(2):130-137. doi:10.1111/resp.13 196

2. Novel Coronavirus Pneumonia Emergency Response Epidemiology Team. The Epidemiological Characteristics of an Outbreak of 2019 Novel Coronavirus Diseases (COVID-19) in China. Zhonghua Liu Xing Bing Xue Za Zhi. 2020;41(2):145-151. doi:10.3760/cma.j. issn.0254-6450.2020.02.003

3. Li YC, Bai WZ, Hashikawa T. The neuroinvasive potential of SARSCoV2 may play a role in the respiratory failure of COVID-19 patients. J Med Virol. 2020;92(6):552-555. doi:10.1002/jmv.25728

4. Shigemura J, Ursano RJ, Morganstein JC, Kurosawa M, Benedek DM. Public responses to the novel 2019 coronavirus (2019-nCoV) in Japan: Mental health consequences and target populations. Psychiatry Clin Neurosci. 2020;74(4):281-282. doi:10.1111/pcn.1298

5. European Centre for Disease Prevention and Control. Factsheet for health professionals on Coronaviruses 2019. Available from: https:// wwwecdceuropaeu/en/factsheet-health-professionals-coronaviruses. Accessed July 30, 2020.
6. European Centre for Disease Prevention and Control. Event background COVID-19. Available from: https://www.ecdc.europa.eu/en/ novel-coronavirus-china. Accessed July 30, 2020.

7. World health organization. Report of the WHO-China Joint Mission on Coronavirus Disease (COVID-19). Available from: https://www. who.int/docs/default-source/coronaviruse/who-china-joint-missionon-covid-19-final-report.pdf. Accessed July 30, 2020.

8. Coronavirus COVID-19 Global Cases by the Center for Systems Science and Engineering at Johns Hopkins. Available from: https:// coronavirus.jhu.edu/map.html. Accessed April 5., 2020

9. Key Messages and Actions for COVID-19 Prevention and Control in Schools. Available from: https://www.who.int/docs/default-source/corona viruse/key-messages-and-actions-for-covid-19-prevention-and-control-in -schools-march-2020.pdf?sfvrsn=baf81d52_. Accessed July 30, 2020.

10. Coronavirus disease 2019 (COVID-19) Situation Report 35. Available from: https://apps.who.int/iris/handle/10665/331221. Accessed July 30, 2020.

11. Coronavirus disease 2019 (COVID-19). Available from: https://www. cdc.gov/coronavirus/2019ncov/about/transmission.html. Accessed July 30, 2020.

12. WHO Director-General's opening remarks at the mission briefing on COVID-19. Available from: https://www.who.int/dg/speeches/detail/ who-director-general-s-opening-remarks-at-the-mission-briefing-oncovid-19. Accessed July 30, 2020.

13. WHO Infection prevention and control guidance - (COVID-19). Available from: https://www.who.int/emergencies/diseases/novelcoronavirus-2019/technical-guidance/infection-prevention-andcontrol. Accessed July 30, 2020.

14. Ethiopian Fedral Ministry of health. National Comprehensive Covid19 Management Handbook. 1st ed. Addis Ababa; April 2020.

15. Zhong B-L, Luo W, Li H-M, et al. Knowledge, attitudes, and practices towards COVID-19 among Chinese residents during the rapid rise period of the COVID-19 outbreak: a quick online cross-sectional survey. Int J Biol Sci. 2020;16(10):1745-1752. doi:10.7150/ijbs. 45221. Available from: http://www.ijbs.com/v16p1745.htm.

16. Abdelhafiz AS, Mohammed Z, Ibrahim ME, et al. Knowledge, perceptions, and attitude of Egyptians towards the novel disease (COVID-19). J Community Health. doi:101007/s10900-020-00827-7

17. Hussain A, Garima T, Singh B, Ram R, Tripti R. Knowledge, attitudes, and practices towards COVID-19 among Nepalese Residents: A quick online cross-sectional survey. Asian Journal of Medical Sciences. 2020;11(3):6-11. doi:10.3126/ajms.v11i3.28485

18. Kebede Y, Yitayih Y, Birhanu Z, Mekonen S, Ambelu A. Knowledge, perceptions and preventive practices towards COVID-19 early in the outbreak among Jimma university medical center visitors, Southwest Ethiopia. PLoS ONE. 2020;15(5):e0233744. doi:10.1371/journal. pone. 0233744

19. Bawazir A, Al-Mazroo E, Jradi H, Ahmed A, Badri M. MERS-CoV infection: mind the public knowledge gap. J Infect Public Health. 2018;11(1):89-93. doi:101016/jjiph201705003

20. Rahman A, Sathi NJ. Knowledge, attitude, and preventive practices toward COVID-19 among Bangladeshi internet users. Electron J Gen Med. 2020;17(5):em245. doi:10.29333/ejgm/8223

International Journal of General Medicine

Dovepress

\section{Publish your work in this journal}

The International Journal of General Medicine is an international, peer-reviewed open-access journal that focuses on general and internal medicine, pathogenesis, epidemiology, diagnosis, monitoring and treatment protocols. The journal is characterized by the rapid reporting of reviews, original research and clinical studies

across all disease areas. The manuscript management system is completely online and includes a very quick and fair peer-review system, which is all easy to use. Visit http://www.dovepress.com/ testimonials.php to read real quotes from published authors. 